ORIGINAL ARTICLE

\title{
Hereditary breast/ovarian and colorectal cancer genetics knowledge in a national sample of US physicians
}

\author{
L Wideroff, S T Vadaparampil, M H Greene, S Taplin, L Olson, A N Freedman
}

J Med Genet 2005;42:749-755. doi: 10.1136/jmg.2004.030296

See end of article for authors' affiliations

\section{Correspondence to:} Dr L Wideroff, NCl/ARP, EPN 4005 MSC 7344 6130 Executive Boulevard, Bethesda, MD 20892-

7344, USA; wideroff@ nih.gov

Received

21 December 2004

Revised 14 March 2005

Accepted for publication 15 March 2005

\begin{abstract}
Background: Clinically relevant genetics knowledge is essential for appropriate assessment and management of inherited cancer risk, and for effective communication with patients. This national physician survey assessed knowledge regarding basic cancer genetics concepts early in the process of introduction of predictive genetic testing for breast/ovarian and hereditary non-polyposis colorectal cancer (HNPCC) syndromes.

Methods: A stratified random sample was selected from the American Medical Association Masterfile of all licensed physicians. In total, 1251 physicians (820 in primary care, 431 in selected subspecialties) responded to a 15 minute questionnaire (response rate 71\%) in 1999-2000. Multivariate logistic regression analyses were conducted to identify demographic and practice characteristics associated with accurate response to three knowledge questions.

Results: Of the study population, $37.5 \%$ was aware of paternal inheritance of BRCA1/2 mutations, and $33.8 \%$ recognised that these mutations occur in $<10 \%$ of breast cancer patients. Only $13.1 \%$ accurately identified HNPCC gene penetrance as $\geqslant 50 \%$. Obstetrics/gynaecology physicians, oncologists, and general surgeons were significantly more likely than general and family practitioners to respond accurately to the breast/ovarian questions, as were gastroenterologists to the HNPCC question.

Conclusions: These nationally representative data indicate limited physician knowledge about key cancer genetics concepts in 1999-2000, particularly among general primary care physicians. Specialists were more knowledgeable about syndromes they might treat or refer elsewhere. Recent dissemination of practice guidelines and continued expansion of relevant clinical literature may enhance knowledge over time. In addition to educational efforts to assist physicians with the growing knowledge base, more research is needed to characterise the organisational changes required within the healthcare system to provide effective cancer genetics services.
\end{abstract}

$\mathrm{T}$ he past 10 years have seen a substantial increase in clinical research to develop appropriate risk assessment and management practices for patients at high risk of breast, ovarian, and colorectal malignancy. ${ }^{1-3}$ The continued expansion and dissemination of an evidence base may significantly reduce the physician knowledge gaps that were first identified during the early period of cancer susceptibility gene characterisation. ${ }^{4}$ Competent knowledge of cancer genetics is essential for effectively assessing and managing risk, deciding when to refer for specialty follow up, and communicating with patients and families. The manner in which physicians frame the discussion of inherited risk and options for screening or risk reducing treatment may strongly influence patient decision making. ${ }^{5}$ In one study, newly diagnosed breast cancer patients with suspected hereditary disease were five times more likely to undergo bilateral mastectomy compared with other or no surgery) if they reported receiving physician recommendations for the procedure, independent of BRCAl/2 genetic test results. ${ }^{6}$

In 1999-2000, a national survey that examined use of and attitudes towards predictive tests for cancer risk, and the state of knowledge about key cancer genetics concepts was conducted with US physicians in primary care and selected specialties $^{78}$. This study provides nationally representative baseline data about responses to three knowledge questions ascertained at an early period in the diffusion of predictive testing into clinical practice, and evaluates physician and practice characteristics associated with accurate responses. This report also describes awareness regarding commercial availability of predictive tests for germline mutations in the $B R C A 1 / 2, M L H 1 / M S H 2$, and APC genes, which were developed in 1991-95 and marketed in the mid to late 1990s, prior to questionnaire administration. ${ }^{10}{ }^{11}$

\section{METHODS}

\section{Survey methods}

Following IRB approval, a nationally representative, stratified random sample of 2079 physicians was selected from the American Medical Association (AMA) Physician Masterfile, a database of all licensed physicians, independent of AMA membership. Practising physicians whose primary professional activity was patient care, and who were licensed to practice medicine in the state of their preferred mailing address, were stratified by specialty and systematically sampled by a fractional sampling interval after sorting by census region, urban/rural location, and sex. The physicians were selected from four primary care specialties (general internal medicine, general practice, family practice, and obstetrics/gynaecology), and four other specialties likely to provide care for cancer patients or patients at high cancer risk (oncology, general surgery, urology, and gastroenterology). They were sampled in proportion to the representation of their specialty in the US physician population, except oncologists, who were oversampled.

Recruitment methods have been described in detail elsewhere. ${ }^{7}$ Data collection commenced on 27 September 1999 , and ended 31 March 2000. Consent was indicated by return of a self administered questionnaire by mail, fax, or a

Abbreviations: AMA, American Medical Association; HMO, health maintenance organisation; HNPCC, hereditary non-polyposis colorectal cancer 
Table 1 Physician responses to questions about BRCA 1 and 2 mutations, by specialty and practice characteristics

\begin{tabular}{|c|c|c|c|c|c|c|c|c|c|c|}
\hline \multirow[b]{2}{*}{ Characteristics } & \multicolumn{5}{|c|}{$\begin{array}{l}\text { Suppose you had a patient whose aunt or grandmother on } \\
\text { her father's side carries the BRCAI gene mutation for } \\
\text { breast/ovarian cancer syndrome. In your opinion, could } \\
\text { your patient also be a carrier of this mutation?*}\end{array}$} & \multicolumn{5}{|c|}{$\begin{array}{l}\text { In your opinion, what percentage of female breast cancer } \\
\text { patients have a BRCA1 or BRCA2 gene mutation?*}\end{array}$} \\
\hline & Yes (\%) & No (\%) & $\begin{array}{l}\text { Not } \\
\text { sure (\%) }\end{array}$ & ORt & $95 \% \mathrm{Cl}$ & $<10(\%)$ & $10-$ & $\begin{array}{l}\text { Not } \\
\text { sure }(\%)\end{array}$ & OR $\ddagger$ & $95 \% \mathrm{Cl}$ \\
\hline \multirow{2}{*}{\multicolumn{11}{|c|}{ Medical specialty }} \\
\hline & & & & & & & & & & \\
\hline Family/general practice & 28.1 & 10.8 & 58.0 & 1.0 & - & 21.8 & 26.7 & 49.1 & 1.0 & - \\
\hline Internal medicine & 37.3 & 11.3 & 47.7 & 1.3 & 0.9 to 1.8 & 29.5 & 30.8 & 36.6 & 1.4 & 0.9 to 2.0 \\
\hline Obstetricians/gynaecologists & 51.9 & 11.9 & 34.4 & 2.0 & 1.3 to 3.0 & 53.6 & 29.3 & 16.5 & 3.0 & 1.9 to 4.6 \\
\hline Oncologists & 66.8 & 7.6 & 21.8 & 3.4 & 2.2 to 5.3 & 71.0 & 21.5 & 4.2 & 5.7 & 3.6 to 9.0 \\
\hline General surgeons & 45.0 & 13.7 & 38.8 & 1.7 & 1.1 to 2.7 & 57.8 & 20.5 & 20.9 & 4.6 & 2.9 to 7.4 \\
\hline Gastroenterologists & 24.8 & 6.7 & 68.5 & 0.6 & 0.3 to 1.4 & 22.4 & 19.9 & 57.9 & 0.9 & 0.4 to 2.2 \\
\hline \multicolumn{11}{|l|}{ Age } \\
\hline$\geqslant 60$ & 37.3 & 5.8 & 53.4 & 1.0 & - & 28.7 & 19.7 & 49.2 & 1.0 & - \\
\hline $40-59$ & 36.7 & 11.6 & 48.5 & 0.9 & 0.6 to 1.3 & 34.7 & 27.5 & 35.6 & 1.4 & 0.9 to 2.0 \\
\hline$<40$ & 40.2 & 11.0 & 46.6 & 1.1 & 0.7 to 1.8 & 34.8 & 33.7 & 29.8 & 1.6 & 0.9 to 2.6 \\
\hline \multicolumn{11}{|c|}{ Cancer genetics services provided in past 12 months } \\
\hline None & 33.3 & 9.2 & 54.5 & 1.0 & - & 27.6 & 28.3 & 41.8 & 1.0 & - \\
\hline $\begin{array}{l}\text { Did not order breast/ovarian } \\
\text { cancer genetics tests, but did } \\
\text { order other cancer genetics } \\
\text { tests or referred patients } \\
\text { elsewhere for testing or risk } \\
\text { assessment }\end{array}$ & 45.3 & 12.6 & 40.6 & 1.2 & 0.8 to 1.6 & 45.2 & 27.5 & 26.4 & 1.4 & 1.0 to 1.9 \\
\hline $\begin{array}{l}\text { Ordered breast/ovarian tests } \\
\text { but did not refer patients } \\
\text { elsewhere }\end{array}$ & 54.6 & 17.0 & 25.0 & 1.6 & 0.8 to 3.3 & 55.8 & 21.3 & 19.5 & 2.3 & 1.1 to 4.7 \\
\hline $\begin{array}{l}\text { Both ordered a breast/ovarian } \\
\text { test and referred patients } \\
\text { elsewhere }\end{array}$ & 49.0 & 16.6 & 24.3 & 1.4 & 0.6 to 3.6 & 58.5 & 18.8 & 17.7 & 2.1 & 0.9 to 5.4 \\
\hline \multicolumn{11}{|c|}{ Local facilities for genetic counselling and testing for inherited cancer risk } \\
\hline No & 43.2 & 13.0 & 40.5 & 1.0 & - & 33.6 & 37.0 & 28.8 & 1.0 & - \\
\hline Yes & 41.6 & 9.5 & 48.3 & 1.0 & 0.6 to 1.4 & 43.9 & 28.1 & 26.2 & 1.2 & 0.8 to 1.9 \\
\hline Not sure & 28.6 & 7.7 & 61.4 & 0.7 & 0.4 to 1.0 & 20.6 & 24.4 & 52.7 & 0.6 & 0.4 to 1.0 \\
\hline \multicolumn{11}{|c|}{ Clear guidelines or strategies are not available for managing patients with inherited cancer susceptibility mutations } \\
\hline $\begin{array}{l}\text { Agreed with statement, } \\
\text { somewhat or strongly }\end{array}$ & 40.8 & 12.4 & 45.9 & 1.0 & - & 37.1 & 31.1 & 31.6 & 1.0 & - \\
\hline $\begin{array}{l}\text { Disagreed, somewhat or } \\
\text { strongly }\end{array}$ & 42.1 & 6.5 & 47.5 & 1.1 & 0.7 to 1.7 & 39.9 & 26.4 & 33.7 & 1.0 & 0.6 to 1.6 \\
\hline \multirow{2}{*}{\multicolumn{11}{|c|}{ Received cancer genetic test advertising }} \\
\hline & & & & & & & & & & \\
\hline No or not sure & & & & 1.0 & - & 29.3 & 26.8 & 41.8 & 1.0 & - \\
\hline Yes & & & & 1.3 & 0.9 to 1.8 & 45.7 & 29.8 & 23.7 & 1.2 & 0.8 to 1.6 \\
\hline \multicolumn{11}{|l|}{ Academic affiliation } \\
\hline No & 36.6 & 9.8 & 51.0 & 1.0 & - & 31.8 & 26.3 & 40.0 & 1.0 & - \\
\hline Yes & 39.8 & 11.9 & 45.3 & 1.0 & 0.8 to 1.3 & 37.4 & 30.0 & 31.1 & 1.0 & 0.7 to 1.3 \\
\hline \multicolumn{11}{|l|}{ Specialties in the practice } \\
\hline Single specialty & 36.9 & 10.9 & 49.3 & 1.0 & - & 33.9 & 27.0 & 37.2 & 1.0 & - \\
\hline Multispecialty & 40.8 & 9.9 & 47.6 & 1.1 & 0.8 to 1.6 & 34.8 & 29.4 & 34.9 & 0.9 & 0.6 to 1.4 \\
\hline \multicolumn{11}{|l|}{ Practice arrangement } \\
\hline Full or part owner & 37.6 & 10.1 & 49.6 & 1.0 & - & 33.7 & 26.6 & 37.4 & 1.0 & - \\
\hline $\begin{array}{l}\text { Employee of physician } \\
\text { practice, HMO, hospital, } \\
\text { university, or clinic }\end{array}$ & 38.0 & 11.0 & 48.5 & 1.0 & 0.8 to 1.4 & 33.9 & 28.4 & 36.5 & 1.1 & 0.8 to 1.6 \\
\hline $\begin{array}{l}\text { *Unadjusted percentages represen } \\
\text { add to } 100 \% \text { due to nonresponse to } \\
\text { (referent category = no or not sur } \\
\text { variable in the logistic regression } n \\
\text { Weighted ORs and } 95 \% \mathrm{Cl} \text { are a }\end{array}$ & $\begin{array}{l}\text { phys } \\
\text { ome it } \\
\text { Weig } \\
\text { del is } \\
\text { sted fo }\end{array}$ & $\begin{array}{l}\text { The } \\
\text { odds } r \\
\text { standi } \\
\text { variak }\end{array}$ & $\begin{array}{l}\text { R) and } \\
10 \%\end{array}$ & u & $\begin{array}{l}\text { pulation of } \\
\text { regression r } \\
\text { intervals (C } \\
\text { ancer patier } \\
\text { naintenance }\end{array}$ & $\begin{array}{l}\text { cians } \\
\text { is av }\end{array}$ & $\begin{array}{l}\text { e selec } \\
\text { aness th } \\
\text { for all } \\
\text { ation ( } r\end{array}$ & $\begin{array}{l}\text { specia } \\
\text { a mutati } \\
\text { ariables } \\
\text { erent cat }\end{array}$ & $\begin{array}{l}\text { Row } \\
\text { can be } \\
\text { he tak } \\
\text { rry }=1\end{array}$ & $\begin{array}{l}\text { entages may not } \\
\text { ited from father } \\
\text { The dependent } \\
0 \% \text { or not sure). }\end{array}$ \\
\hline
\end{tabular}

password protected Internet site, or by verbal agreement to participate in a telephone interview. The questionnaire (available at the Internet site http://riskfactor.cancer.gov/ studies/physician/status.html) took an average of 15 minutes to complete. The final sample size was 1251, which included 820 primary care physicians and 431 other specialists. The overall response rate was $71.0 \%$.

\section{Statistical analysis}

The first cancer genetics knowledge question assessed awareness that BRCA1 and BRCA2 mutations, which are associated with hereditary breast and ovarian cancers, can be transmitted through paternal inheritance. The second question asked what percentage of female breast cancer patients will have BRCA mutations $(<10 \%$ was considered accurate), and the third question asked about penetrance of mutations in the DNA mismatch repair genes $M L H 1$ and MSH2, which are associated with hereditary non-polyposis colorectal cancer (HNPCC) $(\geqslant 50 \%$ penetrance was considered accurate). It was hypothesised that physicians would be more likely to respond accurately if they: $(a)$ were in medical specialties involving frequent management of high risk patients (that is, oncologists, obstetricians/gynaecologists, and gastroenterologists); (b) could interact readily with cancer genetics specialists or seek access to cancer genetics information (that is, they knew of local facilities for genetic 
testing and counselling, believed that relevant practice guidelines were available, had previous exposure to genetic test advertisements, had an academic affiliation, practised in a multispecialty setting, or were employees in a health maintenance organisation, university, or other setting (rather than being full or part owners of a practice));(c) had provided a full range of cancer genetics services within the past 12 months (that is, both ordered genetic tests and referred patients elsewhere for testing or risk assessment) or, to a lesser extent, provided at least some type of service (that is, either ordered or referred); and $(d)$ had more recent medical training (that is, younger age at the time of survey response).

Following bivariate analyses to assess response distributions by physician and practice characteristics, multivariate analyses were conducted to test these hypotheses. Independent variables were entered into full logistic regression models, in which the dependent variable was accurate response (versus inaccurate or unsure). Odds ratios (OR) and 95\% confidence intervals (CI) were computed to assess associations adjusting for covariates. Non-significant variables were eliminated from the regression models in backwards fashion. All analyses were weighted using SUDAAN software. ${ }^{12}$ The weight for each respondent consisted of the total number of US physicians in each physician's specialty, divided by the number of physicians in the specialty that had been sampled for the survey. The weight was multiplied by a non-response factor. Urologists $(n=45)$ were excluded, owing to small numbers and limited relevance of the research questions to their practice.

\section{RESULTS}

\section{BRCA 1/2 paternal inheritance}

As shown in table 1, slightly over one third of respondents accurately recognised that patients could inherit BRCA1/2 mutations through their fathers. Approximately $10 \%$ did not respond accurately, and one half were uncertain. Statistically significant differences were observed between medical specialties $(p<0.0005)$, with awareness of paternal inheritance highest among oncologists and obstetricians/gynaecologists, and lowest among gastroenterologists and family/ general practitioners.

In multivariate analysis (table 1), awareness remained significantly higher among oncologists, followed by obstetricians/gynaecologists and general surgeons, relative to family or general practitioners. Physicians who were uncertain about the availability of clear guidelines or strategies for managing high risk patients were less likely to be aware of paternal inheritance (referent group "believed guidelines were unavailable"). A marginal inverse association was also observed for uncertainty about availability of local genetic testing and counselling facilities (referent group "had no facilities"). ORs suggested a somewhat higher likelihood of accurate response among physicians who had provided some type of cancer genetics services or received genetic test advertisements during the past 12 months compared with those who had not.

\section{Percentage of breast cancer patients with BRCA I/2 mutations}

Overall, one third of physicians accurately responded that $<10 \%$ of female breast cancer patients carry BRCAl/2 mutations (table 1). This percentage varied by specialty $(\mathrm{p}<0.0005)$, ranging from $21.8 \%$ of family/general practitioners to $53.6 \%$ of obstetricians/gynaecologists and $71.0 \%$ of oncologists. Approximately a quarter of respondents overestimated the percentage of carriers, and one third were not sure. The percentage of unsure responses was markedly low among oncologists $(4.2 \%)$.
In multivariate analysis, the likelihood of an accurate response was significantly higher among oncologists, obstetricians/gynaecologists, and general surgeons, relative to general or family practitioners. Response accuracy was also significantly associated with having directly ordered a breast/ ovarian genetic test. ORs for having provided other types of cancer genetics services (that is, "both ordered a breast/ ovarian genetic test and referred patients elsewhere", "only made referrals", or "only ordered other cancer genetic tests") were also higher. Accuracy was inversely associated with uncertainty about the availability of guidelines for testing, and marginally with uncertainty about local genetic testing and counselling facilities. Accuracy increased somewhat with decreasing age; however, the test for trend was not statistically significant $(p=0.08)$.

\section{Penetrance of HNPCC mutations}

As shown in table 2, one third of physicians underestimated the penetrance of HNPCC associated mutations, responding that colorectal cancer developed in $<50 \%$ of carriers. An additional $13.1 \%$ accurately responded that penetrance was $\geqslant 50 \%$, while half $(50.9 \%)$ were not sure. Differences in accuracy were statistically significant across specialties $(\mathrm{p}<0.0005)$. Gastroenterologists had the highest percentage of accurate responses (38.9\%), although half of this specialty group $(49.4 \%)$ still underestimated penetrance. Oncologists had the second highest percentage of accurate responses (25.1\%), although this was markedly lower than the percentage that had responded accurately to the breast/ ovarian knowledge questions.

In multivariate analysis, gastroenterologists were six times more likely than family/general physicians to correctly recognise the high penetrance of HNPCC associated mutations, and the likelihood of accurate response was also significantly elevated for oncologists and internists. As with the breast cancer knowledge questions, accuracy was associated with decreasing age (test for trend: $p=0.01$ ), particularly for physicians $<40$ years old relative to those $>60$ years old. Otherwise, knowledge of penetrance was marginally associated with being an employee as opposed to an owner of the practice.

Most ORs in the breast/ovarian and colorectal models were unaltered when variables not significantly associated with response accuracy were eliminated in backwards logistic regression analysis (data not shown). One exception was that the inverse associations of younger age with accurate response became statistically significant in the most parsimonious model ( 1.7 (95\% CI 1.1 to 2.4 ) for $40-59$ years of age and 2.6 ( 1.6 to 4.2 ) for $<40$ years $v 60+$ years).

\section{Commercial availability of tests}

Table 3 shows the percentages of physicians who responded "yes", "no", or "not sure" to the question about commercial availability of predictive tests for mutations in genes associated with four hereditary cancer syndromes. For all specialties except gastroenterology, uncertainty about commercial availability was lowest for BRCAl/2 tests. Among gastroenterologists, only $21.2 \%$ were uncertain about commercial availability of tests for the APC gene (for familial adenomatous polyposis), in contrast to $52.2 \%$ who were uncertain about tests for the MLHI and MSH2 genes.

\section{DISCUSSION}

In this study, practising physicians displayed limited knowledge about the three key cancer genetics concepts. Only $37.5 \%$ of all physicians surveyed were aware that patients could inherit BRCAI/2 mutations from either parent, and one third understood that these mutations occurred in $<10 \%$ of breast cancers. Most notably, the percentage of "not sure" 
Table 2 Physician responses to question about penetrance of HNPCC associated mutations, by specialty, practice characteristics, and age

\begin{tabular}{|c|c|c|c|c|c|}
\hline \multirow[b]{2}{*}{ Characteristics } & \multicolumn{5}{|c|}{$\begin{array}{l}\text { In your opinion, what percentage of patients who carry a gene for } \\
\text { hereditary non-polyposis colorectal cancer will actually go on to } \\
\text { develop colorectal cancer?* }\end{array}$} \\
\hline & $<50(\%)$ & $\geqslant 50(\%)$ & $\begin{array}{l}\text { Not } \\
\text { sure (\%) }\end{array}$ & OR† & $95 \% \mathrm{Cl}$ \\
\hline Total & 33.6 & 13.1 & 50.9 & & \\
\hline \multicolumn{6}{|l|}{ Medical specialty } \\
\hline Family/general practice & 30.0 & 9.3 & 58.1 & 1.0 & - \\
\hline Internal medicine & 32.4 & 17.5 & 46.7 & 1.9 & $1.1-3.0$ \\
\hline Obstetricians/gynaecologists & 35.9 & 5.2 & 57.6 & 0.5 & $0.2-1.1$ \\
\hline Oncologists & 44.1 & 25.1 & 27.1 & 2.7 & $1.5-4.8$ \\
\hline General surgeons & 38.0 & 11.2 & 50.1 & 1.2 & $0.6-2.4$ \\
\hline Gastroenterologists & 49.4 & 38.9 & 11.7 & 6.1 & $2.8-13.4$ \\
\hline \multicolumn{6}{|l|}{ Age } \\
\hline$\geqslant 60$ & 34.2 & 5.9 & 57.6 & 1.0 & - \\
\hline $40-59$ & 33.8 & 13.1 & 50.5 & 1.9 & $1.0-3.8$ \\
\hline$<40$ & 32.2 & 19.0 & 46.6 & 2.7 & $1.3-5.9$ \\
\hline \multicolumn{6}{|c|}{ Cancer genetics services provided in past 12 months } \\
\hline None & 30.9 & 12.4 & 54.3 & 1.0 & - \\
\hline $\begin{array}{l}\text { Did not order colon cancer } \\
\text { genetics tests, but did order other } \\
\text { cancer genetics tests or referred } \\
\text { patients elsewhere for testing or } \\
\text { risk assessment }\end{array}$ & 37.9 & 15.0 & 45.5 & 1.3 & $0.8-2.1$ \\
\hline $\begin{array}{l}\text { Ordered colon cancer tests but did } \\
\text { not refer patients elsewhere }\end{array}$ & 40.8 & 18.5 & 35.2 & 0.9 & $0.3-2.8$ \\
\hline $\begin{array}{l}\text { Both ordered a colon test and } \\
\text { referred patients elsewhere }\end{array}$ & 67.8 & 13.7 & 18.5 & 0.9 & $0.3-3.2$ \\
\hline \multicolumn{6}{|c|}{ Local facilities for genetic counselling and testing for inherited cancer risk } \\
\hline No & 42.1 & 13.8 & 42.7 & 1.0 & - \\
\hline Yes & 37.1 & 14.5 & 46.6 & 1.0 & $0.5-1.8$ \\
\hline Not sure & 26.3 & 11.1 & 60.0 & 0.8 & $0.4-1.6$ \\
\hline \multicolumn{6}{|c|}{ Clear guidelines or strategies are not available for managing patients with inherited cancer susceptibility mutation } \\
\hline $\begin{array}{l}\text { Agreed with statement, somewhat } \\
\text { or strongly }\end{array}$ & 38.6 & 13.8 & 47.0 & 1.0 & - \\
\hline Disagreed, somewhat or strongly & 30.9 & 19.2 & 49.9 & 1.2 & $0.7-2.1$ \\
\hline Not sure & 13.9 & 7.2 & 78.1 & 0.6 & $0.3-1.2$ \\
\hline \multicolumn{6}{|c|}{ Received cancer genetic test advertising } \\
\hline No or not sure & 30.9 & 12.8 & 54.0 & 1.0 & - \\
\hline Yes & 40.7 & 14.1 & 43.6 & 1.1 & $0.7-1.7$ \\
\hline \multicolumn{6}{|l|}{ Academic affiliation } \\
\hline No & 31.9 & 11.4 & 54.3 & 1.0 & - \\
\hline Yes & 36.3 & 16.3 & 45.6 & 1.3 & $0.9-2.0$ \\
\hline \multicolumn{6}{|l|}{ Practice arrangement } \\
\hline Full or part owner & 33.8 & 10.3 & 53.0 & 1.0 & - \\
\hline $\begin{array}{l}\text { Employee of physician practice, } \\
\text { HMO, hospital, university, or clinic }\end{array}$ & 33.1 & 16.9 & 48.7 & 1.6 & $1.0-2.4$ \\
\hline \multicolumn{6}{|l|}{ Specialties in the practice } \\
\hline Single specialty & 33.9 & 11.8 & 51.9 & 1.0 & - \\
\hline Multi specialty & 32.9 & 17.6 & 48.6 & 1.1 & $0.7-1.6$ \\
\hline \multicolumn{6}{|c|}{$\begin{array}{l}\text { *Unadjusted percentages representing physician responses are weighted to the U.S. population of physicians in the } \\
\text { selected specialties. Row percentages may not add to } 100 \% \text { due to item nonresponse. The dependent variable in } \\
\text { the logistic regression model is understanding that } \geqslant 50 \% \text { of carriers of HNPCC associated germline mutations } \\
\text { develop colorectal cancer (versus }<50 \% \text { or not sure as the referent category). Weighted ORs and } 95 \% \mathrm{Cl} \text { are } \\
\text { adjusted for all variables in the table. } \mathrm{HMO} \text {, health maintenance organisation. }\end{array}$} \\
\hline
\end{tabular}

respondents was $49.0 \%$ for the paternal inheritance question, and $36.7 \%$ for the mutation prevalence question, indicating considerable uncertainty about basic breast/ovarian cancer genetics concepts. Similarly, half the physicians were uncertain about the penetrance of HNPCC associated mutations, while only $13.1 \%$ accurately identified penetrance as $\geqslant 50 \%$. In contrast to greater awareness about $B R C A 1 / 2$ test availability, two thirds were unsure about $A P C$ and $M L H I /$ MSH2 tests.

However, genetics knowledge was not uniform across medical specialties, and specialty was a stronger and more consistent determinant of response accuracy than other hypothesised factors, including age or having provided cancer genetics services during the past year. Higher response accuracy among obstetricians/gynaecologists, oncologists, and general surgeons for the breast/ovarian questions, and among gastroenterologists for the HNPCC question, may reflect selective information seeking by specialists who had to meet the needs of their specific patient populations and who, thereby, became early providers of state of the art cancer genetics services. Direct to consumer marketing of genetic tests $^{13}$ and family history assessment tools ${ }^{14}$ may indirectly promote information seeking by primary care providers faced with increasing patient inquiries about inherited risk.

Our findings of uncertainty and limited accuracy related to clinical genetics knowledge are consistent with reported knowledge levels in several regional, ${ }^{13-17}$ national, ${ }^{18}$ and international $^{19-23}$ surveys conducted at a comparable timepoint. In the aggregate, these findings are not unexpected given the relatively recent identification of major breast/ ovarian and colorectal cancer susceptibility genes ${ }^{24} 25$ and the evolving understanding of their clinical implications. Continued expansion of the clinical literature, provider education programmes, and the recent dissemination of new 
Table 3 Weighted percentages* (and 95\% Cl) of physician responses to the question about commercial availability of predictive cancer genetic tests, by medical specialty

\begin{tabular}{|c|c|c|c|c|c|c|c|}
\hline \multirow[b]{3}{*}{ Genes } & \multicolumn{7}{|c|}{ Based on your current knowledge, are tests for the following inherited cancer susceptibility genes commercially available? } \\
\hline & \multicolumn{7}{|l|}{ Medical specialty } \\
\hline & $\begin{array}{l}\text { All specialties } \\
\text { combined }\end{array}$ & $\begin{array}{l}\text { Family or general } \\
\text { practice }\end{array}$ & Internal medicine & $\begin{array}{l}\text { Obstetrics/ } \\
\text { gynaecology }\end{array}$ & Oncologists & General surgeons & $\begin{array}{l}\text { Gastro- } \\
\text { enterologists }\end{array}$ \\
\hline \multicolumn{8}{|c|}{ BRCAl and 2 genes for hereditary breast/ovarian cancer } \\
\hline Yes & $60.7(58.0$ to 63.4$)$ & 44.9 (39.6 to 50.2$)$ & $60.8(55.5$ to 66.1$)$ & $91.2(86.7$ to 95.7$)$ & $90.9(87.0$ to 94.8$)$ & $75.6(68.0$ to 83.2$)$ & $35.3(20.6$ to 50.0$)$ \\
\hline No & $4.0(2.8$ to 5.1$)$ & $4.2(2.0$ to 6.4$)$ & $4.6(2.2$ to 7.0$)$ & $2.6(0.1$ to 5.1$)$ & $1.9(0.1$ to 3.7$)$ & $5.0(1.1$ to 8.9$)$ & $2.5(0.0$ to 7.4$)$ \\
\hline Not sure & $33.2(30.4$ to 35.9 ) & $48.6(43.3$ to 53.9$)$ & $31.6(26.5$ to 36.7$)$ & $5.7(2.2$ to 9.2$)$ & $4.0(1.5$ to 6.5$)$ & $17.7(10.8$ to 24.6$)$ & 62.2 (47.3 to 77 \\
\hline \multicolumn{8}{|c|}{$M L H 1$ and $M S H 2$ genes for hereditary non-polyposis colorectal cancer } \\
\hline Yes & 23.1 (20.6 to 25.6$)$ & $16.8(12.9$ to 20.7$)$ & 22.7 (18.0 to 27.4$)$ & $22.4(15.7$ to 29.1$)$ & $42.8(36.1$ to 49.5$)$ & $35.7(27.1$ to 44.3$)$ & $43.8(28.5$ to 59.1$)$ \\
\hline No & $4.0(2.4$ to 5.6$)$ & $7.1(4.4$ to 9.8$)$ & $7.2(4.5$ to 9.9$)$ & $4.5(1.2$ to 7.8$)$ & $12.4(8.1$ to 16.7$)$ & 7.2 (2.7 to 11.7$)$ & 4.0 (0.0 to 9.7$)$ \\
\hline Not sure & $67.8(65.1$ to 70.5$)$ & $73.2(68.5$ to 77.9$)$ & 67.1 (62.0 to 72.2$)$ & $72.4(65.1$ to 79.7$)$ & $41.5(35.0$ to 48.0$)$ & 55.4 (46.6 to 64.2$)$ & 52.2 (36.9 to 67.5$)$ \\
\hline \multicolumn{8}{|c|}{$A P C$ gene for familial adenomatous polyposis } \\
\hline Yes & 25.7 (23.2 to 28.2$)$ & 19.6 (15.5 to 23.7$)$ & 26.2 (21.3 to 31.1$)$ & 17.5 (11.2 to 23.8 ) & 44.0 (37.3 to 50.7$)$ & 33.0 (24.6 to 41.4$)$ & 76.4 (63.3 to 89.5$)$ \\
\hline No & $5.6(4.2$ to 7.0$)$ & $5.0(2.6$ to 7.4$)$ & 6.2 (3.5 to 8.9$)$ & 5.8 (2.1 to 9.5$)$ & $7.7(4.2$ to 11.2$)$ & $6.3(2.0$ to 10.6$)$ & $2.5(0.0$ to 7.4$)$ \\
\hline Not sure & 66.5 (63.8 to 69.2$)$ & $72.8(68.1$ to 77.5$)$ & $64.5(59.2$ to 69.8$)$ & $76.0(69.1$ to 82.9$)$ & 44.6 (37.9 to 51.3$)$ & $59.0(50.2$ to 67.8$)$ & $21.2(8.7$ to 33.7$)$ \\
\hline
\end{tabular}

*Unadjusted percentages (and 95\% Cl) representing physician responses are weighted to the U.S. population of physicians in the selected specialties. "Yes", "no", and "not sure" percentages within a specialty may not add to $100 \%$ due to non-response for some items.

or updated practice guidelines, ${ }^{26-29}$ should increase cancer genetics knowledge among a broader spectrum of physicians. However, differences in guideline recommendations between various professional organisations can result in practice variability, particularly across medical specialties. ${ }^{30}$

In practice settings where genetic counselling and testing, heightened surveillance, and risk reduction interventions are relevant, physician uncertainty or inaccurate understanding of clinically significant genetics concepts can adversely affect quality of care, resulting in underutilisation of services by high risk groups and overutilisation by low to moderate risk groups. Therefore, accurate knowledge of modes of inheritance, penetrance, mutation prevalence, and management options is essential to properly informed risk assessment and decision making for both the physician and the patient.

For example, consideration of BRCAl/2 testing and referral for genetic counselling may be appropriate for an asymptomatic 55 year old woman whose two paternal aunts had premenopausal breast or ovarian cancers. A physician who is unaware of the autosomal dominant transmission of BRCA1/2 mutations may not obtain sufficient information about, nor give adequate consideration to, a paternal family history of these cancers. Consequently, they may not discuss indicated risk assessment or management options with patients and their families, or may fail to make appropriate referrals that could lead to better understanding of risk reducing interventions, such as tamoxifen, mastectomy, or oophorectomy. In contrast, recommendations for BRCAI/2 testing would be inappropriate for an asymptomatic 55 year old woman whose only family history was a mother diagnosed with ductal carcinoma in situ at the age of 82 years. In this scenario, knowledge of inheritance patterns enables physicians to provide immediate reassurance to patients who harbour anxiety about inherited cancer based on inaccurate risk perceptions. Correction of such misperceptions may also reduce the anxiety that low to moderate risk patients convey to their family members.

Accurate recognition of the low prevalence of $B R C A$ mutations in unselected breast cancer patients is critical to informed use of complex and costly risk assessment options. Physician knowledge about HNPCC gene prevalence is important for similar reasons, although this study did not specifically evaluate this. HNPCC is the most common familial colorectal cancer syndrome, ${ }^{31}$ and, as a disorder of both men and women, the absolute number of affected patients is larger relative to hereditary breast/ovarian cancer. Underestimation of HNPCC prevalence may result in failure to place this condition high enough on the list of diagnostic or aetiological considerations, or to learn about or consider proper syndrome specific evaluation of patients (such as when to test appropriate tumours for microsatellite instability and $\mathrm{MLHI} / \mathrm{MSH} 2$ protein expression by immunohistochemistry or when to consider predictive genetic testing). Underestimation may also result in failure to recommend adequate frequency of colonoscopic surveillance, and to understand the practical implications of the fact that five or six different genes cause this syndrome.

If physicians underestimate HNPCC associated gene penetrance, as our data suggest, they may be less inclined to encourage patients to alert family members about inherited risk, or refer patients to a clinical setting that can provide optimum care. Consequently, the patient may not take the problem seriously enough to implement recommended management guidelines, to consider aggressive approaches to their management, or to alert at risk family members. Asymptomatic carriers may also make erroneous assumptions regarding whether the trait can be passed on to their children, as the concept of being mutation positive but phenotypically normal is confusing.

On the other hand, physician overestimation of penetrance could cause unnecessary alarm for patients, who may fail to appreciate that a substantial number (15-20\%) of HNPCC related gene mutation carriers never develop colorectal cancer. It may also lead to recommendations for inappropriately aggressive management (such as more frequent colonoscopies or more serious consideration of risk reducing colectomy, hysterectomy, or oophorectomy than needed), particularly in the clinical care of families with a history suggestive of HNPCC, in which a deleterious mutation in one of the mismatch repair genes has not been identified. The complexity of HNPCC associated gene penetrance is amplified by the diversity of cancers implicated as part of the syndrome. The managing physician must not only be aware of colorectal cancer penetrance but also penetrance of endometrial (which may reach $60 \%$ among female carriers of HNPCC related mutations), ovarian, gastric, renal, brain, and small bowel cancers. Recognising that other cancers (most notably, endometrial carcinoma) are part of the HNPCC syndrome will have a substantial impact on how a physician interprets family history information and, thus, on the seriousness with which they consider HNPCC as a diagnostic possibility. Finally, it may alter their surveillance recommendations, which may need to take into account patients' susceptibility to a broader range of cancers. 
A major strength of this study is that it provides a nationally representative cross sectional sample of physician knowledge regarding several clinically relevant cancer genetics concepts. The period 1999-2000 represents an early point in the diffusion of commercial tests for inherited cancer susceptibility mutations and the dissemination of clinical recommendations for risk assessment, counselling, and management of carriers. Therefore, these data can serve as a unique national benchmark for studying time trends in knowledge gaps or for comparisons with local estimates. An additional strength is the $71 \%$ response rate, which is unusually high for a physician survey. However, the specialty specific estimates were less stable for small subgroups such as general surgeons and gastroenterologists, and the data on availability of genetic tests should be interpreted cautiously, because "commercial availability" may have had different meanings for different respondents.

In conclusion, this survey confirms the continuing need to raise provider knowledge levels in cancer genetics, especially among primary care physicians. Research suggests that physicians are receptive to educational interventions to strengthen their understanding of cancer genetics, ${ }^{32-34}$ and that they are able to recommend risk reduction options tailored to individual patients' risk levels. ${ }^{35}$ However, lessons drawn from many other areas of medicine indicate that education alone does not necessarily translate into effective adoption of innovative practices. ${ }^{36}{ }^{37}$ Additional research is needed to further characterise contextual factors (such as continuity and quality of care, reimbursement, literacy, and cultural competence) influencing the incorporation of cancer risk assessment and management into clinical practice, ${ }^{38-40}$ and the organisational changes needed within the healthcare system to provide cancer genetics services effectively..$^{41}{ }^{42}$

\section{ACKNOWLEDGEMENTS}

Funding for this project was provided by National Cancer Institute contract N01-PC-85079.

\section{Authors' affiliations \\ L Wideroff, S Taplin, A N Freedman, Applied Research Program/} Division of Cancer Control and Population Sciences, National Cancer Institute, Bethesda, MD, USA

M H Greene, Clinical Genetics Branch/Division of Cancer Epidemiology and Genetics, National Cancer Institute, Bethesda, MD, USA S T Vadaparampil, Health Outcomes and Behavior Program/H Lee Moffitt Cancer Center, Tampa, FL, USA

L Olson, ABT Associates, Chicago, IL, USA

Competing interests: none declared

\section{REFERENCES}

1 Thull DL, Vogel VG. Recognition and management of hereditary breast cancer syndromes. Oncologist 2004;9:13-24.

2 Annie Yu HJ, Lin KM, Ota DM, Lynch HT. Hereditary nonpolyposis colorectal cancer: preventive management. Cancer Treat Rev 2003;29:461-70.

3 Hampel H, Sweet K, Westman JA, Offit K, Eng C. Referral for cancer genetics consultation: a review and compilation of risk assessment criteria. J Med Genet 2004;41:81-91.

4 Hofman KJ, Tambor ES, Chase GA, Geller G, Faden RR, Holtzman NA. Physicians' knowledge of genetics and genetic tests. Acad Med 1993;68:625-32.

5 Tinley ST, Houfek J, Watson P, Wenzel L, Clark MB, Coughlin S, Lynch HT. Screening adherence in BRCA1/2 families is associated with primary care physicians' behavior. Am J Med Genet 2004;125A:5-11.

6 Schwartz MD, Lerman C, Brogan B, Peshkin BN, Halbert CH, DeMarco T, Lawrence $W$, Main D, Finch C, Magnant $C$, Pennanen $M$, Tsangaris $T$, Willey S, Isaacs $C$. Impact of BRCA 1/BRCA2 counseling and testing on newly diagnosed breast cancer patients. J Clin Oncol 2004;22:1823-9.

7 Wideroff L, Freedman AN, Olson L, Klabunde CN, Davis W, Srinath KP, Croyle RT, Ballard-Barbash R. Physician use of genetic testing for cancer susceptibility: results of a national survey. Cancer Epidemiol Biomarkers Prev 2003; 12:295-303.

8 Freedman AN, Wideroff L, Olson L, Davis W, Klabunde C, Srinath KP, Reeve BB, Croyle RT, Ballard-Barbash R. US physicians' attitudes toward genetic testing for cancer susceptibility. Am J Med Genet 2003;120A:63-71.
9 Li FP. Translational research on hereditary colon, breast, and ovarian cancers. Monogr Natl Cancer Inst 1995; 17:1-4.

10 Carter CL, Scott JA, Glauber PM, Murphy PD. The Oncormed approach to genetic testing. Genet Test 1997;1:137-44.

11 Giardiello FM, Brensinger JD, Petersen GM, Luce MC, Hylind LM, Bacon JA Booker SV, Parker RD, Hamilton SR. The use and interpretation of commercial APC gene testing for familial adenomatous polyposis. N Engl J Med 1997:336:823-7.

12 Shah BV, Barnwell BG, Beiler GS. SUDAAN user's manual, Release 7.5. Research Triangle Park, NC: Research Triangle Institute, 1997

13 Jacobellis J, Martin L, Engel J, Van Eenwyk J, Bradley L, Kassim S, Jorgenson C, Litch J, Myers M. Genetic testing for breast and ovarian cancer susceptibility: evaluating direct-to-consumer marketing-Atlanta, Denver, Raleigh-Durham, and Seattle, 2003. Centers for Disease Control and Prevention. MMWR Morb Mortal Wkly Rep 2004;53:603-6.

14 Yoon PW, Scheuner MT, Peterson-Oehlke KL, Gwinn M, Faucett A, Khoury MJ. Awareness of family health history as a risk factor for disease-United States, 2004. MMWR Morb Mortal Wkly Rep 2004;53:1044-7.

15 Mouchawar J, Klein C, Mullineaux L. Colorado family physicians' knowledge of hereditary breast cancer and related practice. J Cancer Educ $2001 ; 16: 33-7$

16 Sifri R, Myers R, Hyslop T, Turner B, Cocroft J, Rothermel T, Grana J, Schlackman N. Use of cancer susceptibility testing among primary care physicians. Clin Genet 2003;64:355-60.

17 Batra S, Valdimarsdottir H, McGovern M, Itzkowitz S, Brown K. Awareness of genetic testing for colorectal cancer predisposition among specialists in gastroenterology. Am J Gastroenterol 2003;97:729-33.

18 Wilkins-Haug L, Hill LD, Power ML, Holzman GB, Schulkin J. Gynecologists' training, knowledge, and experiences in genetics: a survey. Obstet Gynecol 2000;95:421-4.

19 Escher M, Sappino AP. Primary care physicians' knowledge and attitudes towards genetic testing for breast-ovarian cancer predisposition. Ann Oncol 2000;11:1131-5

20 Pichert G, Dietrich D, Moosmann P, Zwahlen M, Stahel RA, Sappino AP. Swiss primary care physicians' knowledge, attitudes, and perception towards genetic testing for hereditary breast cancer. Fam Cancer 2003;2:153-8.

21 Julian-Reynier C, Eisinger F, Moatti JP, Sobol H. French physicians' knowledge about hereditary breast/ovarian cancer: the need for continuing vocational education in genetics. Community Genet 1999;2:165-72.

22 Yong MC, Zhou XJ, Lee SC. The importance of paternal family history in hereditary breast cancer is underappreciated by health care professionals. Oncology 2003;64:220-6.

23 Hunter A, Wright P, Cappelli M, Kasaboski A, Surh L. Physician knowledge and attitudes towards molecular genetic (DNA) testing of their patients. Clin Genet 1998;53:447-55

24 Miki Y, Swensen J, Shattuck-Eidens D, Futreal PA, Harshman K, Tavtigian S, Liu Q, Cochran C, Bennett LM, Ding W, Bell R, Rosenthal J, Hussey C, Tran T, McClure M, Frye C, Hattier T, Phelps R, Haugen-Strano A, Katcher $H_{\text {, }}$ Yakumo K, Gholami A, Shaffer D, Stone S, Bayer S, Wray C, Bogden R, Dayananth P, Ward J, Tonin P, Narod S, Bristow PK, Norris FH, Helvering L, Morrison P, Rosteck P, Lai M, Barrett JC, Lewis C, Neuhausen S, CannonAlbright L, Goldgar D, Wiseman R, Kamb A, Skolnick MH. A strong candidate for the breast and ovarian cancer susceptibility gene BRCA 1 Science 1994;266:66-71

25 Wooster R, Bignell G, Lancaster J, Swift S, Seal S, Mangion J, Collins N, Gregory S, Gumbs C, Micklem G. Identification of the breast cancer susceptibility gene BRCA2. Nature 1995;378:789-92.

26 American Society of Clinical Oncology. American Society of Clinical Oncology policy statement update: genetic testing for cancer susceptibility. $J$ Clin Oncol 2003;21:2397-406.

27 American College of Medical Genetics/American Society of Human Genetics. Genetic testing for colon cancer: joint statement of the American College of Medical Genetics and American Society of Human Genetics. Genet Med 2000;2:362-6

28 American Gastroenterological Association. American Gastroenterological Association medical position statement: hereditary colorectal cancer and genetic testing. Gastroenterology 2001;121:195-7

29 National Comprehensive Cancer Network. Genetic/familial high-risk screening. Practice Guidelines in oncology, version 1.2004. www.nccn.org/ index.html. Accessed 9 August, 2004.

30 Schroy PC 3rd, Barrison AF, Ling BS, Wilson S, Geller AC. Family history and colorectal cancer screening: a survey of physician knowledge and practice patterns. Am J Gastroenterol 2002;97:1031-6.

31 Terdiman JP. HNPCC: an uncommon but important diagnosis Gastroenterology 2001;121:1005-8.

32 Blazer KR, Grant M, Sand SR, MacDonald DJ, Uman GC, Weitzel JN. Effects of a cancer genetics education programme on clinician knowledge and practice. J Med Genet 2004:41:518-22.

33 Lapham EV, Kozma C, Weiss JO, Benkendorf JL, Wilson MA. The gap between practice and genetics education of health professionals: HUGEM survey results. Genet Med 2000;2:226-31.

34 Burke W, Emery J. Genetics education for primary care providers. Nat Rev Genet 2002;3:561-6.

35 Haas JS, Kaplan CP, Gregorich SE, Perez-Stable EJ, Des Jarlais G. Do physicians tailor their recommendations for breast cancer risk reduction based on patient's risk? J Gen Intern Med 2004;19:302-9.

36 Winkler JD, Lohr KN, Brook RH. Persuasive communication and medical technology assessment. Arch Intern Med 1985;145:314-17.

37 Stone EG, Morton SC, Hulscher ME, Maglione MA, Roth EA, Grimshaw JM, Mittman BS, Rubenstein LV, Rubenstein LZ, Shekelle PG. Interventions that 
increase use of adult immunization and cancer screening services: a meta-analysis. Ann Intern Med 2002;136:641-51.

38 Worthen HG. Inherited cancer and the primary care physician; barriers and strategies. Cancer 1999;86:2583-8S

39 Koil CE, Everett JN, Hoechstetter L, Ricer RE, Huelsman KM. Differences in physician referral practices and attitudes regarding hereditary breast cancer by clinical practice location. Genet Med 2003;5:364-9.

40 Bouchard L, Blancquaert I, Eisinger F, Foulkes WD, Evans G, Sobol H, Julian-Reynier C. Prevention and genetic testing for breast cancer: variations in medical decisions. Soc Sci Med

2004;58:1085-96.

41 Walsh JME, McPhee SJ. A systems model of clinical preventive care: an analysis of factors influencing patient and physician. Health Ed $Q$ 1992; 19:157-75.

42 Mouchawar J, Valentine Goins K, Somkin C, Puleo E, Hensley Alford S, Geiger AM, Taplin S, Gilbert J, Weinmann S, Zapka J. Guidelines for breast and ovarian cancer genetic counseling referral: adoption and implementation in HMOs. Genet Med 2003;5:444-50.

\section{Clinical Evidence - Call for contributors}

Clinical Evidence is a regularly updated evidence-based journal available worldwide both as a paper version and on the internet. Clinical Evidence needs to recruit a number of new contributors. Contributors are healthcare professionals or epidemiologists with experience in evidence-based medicine and the ability to write in a concise and structured way.

Areas for which we are currently seeking authors:

- Child health: nocturnal enuresis

- Eye disorders: bacterial conjunctivitis

- Male health: prostate cancer (metastatic)

- Women's health: pre-menstrual syndrome; pyelonephritis in non-pregnant women

However, we are always looking for others, so do not let this list discourage you.

Being a contributor involves:

- Selecting from a validated, screened search (performed by in-house Information Specialists) epidemiologically sound studies for inclusion.

- Documenting your decisions about which studies to include on an inclusion and exclusion form, which we keep on file.

- Writing the text to a highly structured template (about 1500-3000 words), using evidence from the final studies chosen, within 8-10 weeks of receiving the literature search.

- Working with Clinical Evidence editors to ensure that the final text meets epidemiological and style standards.

- Updating the text every six months using any new, sound evidence that becomes available. The Clinical Evidence in-house team will conduct the searches for contributors; your task is simply to filter out high quality studies and incorporate them in the existing text.

- To expand the topic to include a new question about once every 12-18 months.

If you would like to become a contributor for Clinical Evidence or require more information about what this involves please send your contact details and a copy of your CV, clearly stating the clinical area you are interested in, to Klara Brunnhuber (kbrunnhuber@ bmigroup.com).

\section{Call for peer reviewers}

Clinical Evidence also needs to recruit a number of new peer reviewers specifically with an interest in the clinical areas stated above, and also others related to general practice. Peer reviewers are healthcare professionals or epidemiologists with experience in evidence-based medicine. As a peer reviewer you would be asked for your views on the clinical relevance, validity, and accessibility of specific topics within the journal, and their usefulness to the intended audience (international generalists and healthcare professionals, possibly with limited statistical knowledge). Topics are usually 1500-3000 words in length and we would ask you to review between 2-5 topics per year. The peer review process takes place throughout the year, and our turnaround time for each review is ideally 10-14 days.

If you are interested in becoming a peer reviewer for Clinical Evidence, please complete the peer review questionnaire at www.clinicalevidence.com or contact Klara Brunnhuber (kbrunnhuber@bmigroup.com). 